\title{
Genetic Diversity and Correlation for Grain Yield and Quality Traits in Local Maize (Zea mays L.)
}

\author{
Sali ALIU', Imer RUSINOVCI ${ }^{1}$, Shukri FETAHU' ${ }^{1}$, Ludvik ROZMAN² \\ ${ }^{1}$ The University of Prishtina, Faculty of Agriculture and Veterinary, Department of Crop Science, Bill \\ Clinton St, N.N.Prishtina, Kosovo; salialiu02@gmail.com (*corresponding author) \\ ${ }^{2}$ University of Ljubljana, Biotechnical Faculty, 101 Jamnikarjeva St., Slovenia
}

\begin{abstract}
The aim of the study was to estimate the genetic diversity and correlation analysis among yield and quality traits in 20 local maize populations. The study of variation included the quantity of grain yield, and quality traits such as protein, oil and starch content in grain. Results showed that there were significant differences among the populations. The mean grain yield of all populations was $79.33 \mathrm{~g}$ plant ${ }^{-1}$ and the highest in 'GBK-7' (105.13 g plant $^{-1}$ ). Protein and oil contents ranged between 11.02 to $13.02 \%$ and 2.56 to $5.57 \%$, respectively and starch content varied from 68.58 to $70.92 \%$. First two canonical discriminant functions were significant $(p<0.01)$ and the relevance of the first two discriminant functions justifying $95.80 \%$ variability among populations. There were also big differences regarding phenotypic correlations. Study suggests that the quality traits are phenotypically and genotypically highly variable and therefore very useful for breeding program.
\end{abstract}

Keywords: local maize populations, protein, oil, starch

\section{Introduction}

Maize (Zea mays L.) is considered to be a major source of food for livestock and humans because of its relatively high content of proteins, oil, starch and some other important vitamins such as vitamin B and B12. Yellow maize can provide a substantial amount of vitamin $A$, and the maize germ is rich in vitamin E (Okoruwa et al., 1996). The maize crop is considered to be an integral part of Kosova's agricultural production system and has a potential to compete with other crops. In order to have access to the global market, there is need to improve the yield quality with judicious use of inputs (Saleem et al., 2008). Maize is commonly used in animal feed as an energy source, owing to its high starch content, which gives it priority over all other cultivated cereals (Oliveira et al., 2006). Several million people, particularly in developing countries, derive their protein and calorie requirements from maize. Some of the most important traits of interest in the maize market are protein and oil content. The protein content (PC) is a quantitative trait and several studies have pointed out that there is a great number of genes involved in its control (Mittelman et al., 2003). Protein is an expensive but necessary constituent of both food and feed. Grain protein quantity in ordinary maize is relatively low $\left(80-110 \mathrm{~g} \mathrm{~kg}^{-1}\right)$ and of poor quality because of low levels of amino acids, lysine and tryptophan (Bjarnason and Vasal, 1992). Maize protein which ranges from 6 to $12 \%$ is regarded to be inferior because it is low in lysine and tryptophan (FAO,
1988). This may cause nutritional deficiencies when maize is used as an exclusive protein source, without the addition of supplements (Glover and Mertz, 1987). Some proteins in maize have anti-fungal qualities. The basis of resistance to fungal infection may lie with protein content, type, or distribution in tissue (Guo et al., 1997). The existence of genetic variability and the prospect of selection for protein content in maize have been demonstrated in several studies (Micu et al., 1995). Most of the oil is in the germ of the kernel. Oil and protein contents have been increased to levels almost twice as high as those of the original grain (Jugenheimer, 1961). High-oil corn (HOC) inbreeds were first developed in 1896 and some hybrids containing $6-8 \%$ oil (Haumann, 1996), and affected by the size of embryo, maturity, and position of the kernel on the ear (Lambert, 2001). Breeding studies in maize to enhance fatty acid composition started in 1970's; however, they have not continued. Research in this area dealt with different aspects to grain quality, focusing mainly on determination of the grain quality traits and characterization of maize genotypes in terms of fatty acid composition (Egesel et al., 2011). The major use of HOC is in livestock feed because of its higher metabolizable energy value (Weber, 1987). The developing countries have more areas dedicated to maize cultivation than developed countries, but yield in the latter is about four times higher. While most production in developing countries is used for human consumption, in developed world, it is mainly used for animal feed and industry (FAO, 1988). As indicated earlier, maize 
has three possible uses such as food, feed for livestock and raw material for industry. Maize is one of the most important grain crops in Kosovo, with over 60,000 hectares in production (MAFRD, 2010). However, the surface under local maize populations is more than $5 \%$. In most cases, the cultivation of local populations is associated with their adaptability to specific environments and also with their nutritional value because it is frequently used for human consumption as corn bread that can be consumed together with milk. In this way, the main objective of the present study and based on the descriptive results of twenty local maize populations the present paper tries to analyze of the mentioned maize local populations, and also the identification of the quality traits with more differentiating ability.

\section{Materials and methods}

\section{Plant material and experimental design}

Twenty local maize populations (LMP), collected from different regions of Kosova, were used in this study (Tab. 1). The experiment was carried out in a randomized complete block design with three replicates in Prishtina $42^{\circ} 38^{\prime} 29.76^{\prime \prime} \mathrm{N}$ and $21^{\circ} 07^{\prime} 16.49^{\prime \prime} \mathrm{E}$ on $571 \mathrm{~m}$ of altitude. The climate of the region is semiarid with hot summers. The soil in the experimental area is classified as vertisol (black soil). Standard agronomic practices were used to provide adequate nutrition and keep the plots disease free.

Tab. 1. Geographical data of investigated Kosovo local maize populations

\begin{tabular}{|c|c|c|c|c|}
\hline Populations & $\begin{array}{c}\text { Geographical } \\
\text { origin }\end{array}$ & Longitude & Latitude & $\begin{array}{c}\text { Elevation } \\
(\mathrm{m})\end{array}$ \\
\hline 'GBK-1' & Drenas & $20^{\circ} 44^{\prime} 43^{\prime \prime}$ & $42^{\circ} 41^{\prime} 50^{\prime \prime}$ & 567 \\
\hline 'GBK-2’’ & Malisheve & $20^{\circ} 44^{\prime} 09^{\prime \prime}$ & $42^{\circ} 28^{\prime} 12^{\prime \prime}$ & 562 \\
\hline 'GBK-3’' & Malisheve & $20^{\circ} 43^{\prime} 22^{\prime \prime}$ & $42^{\circ} 27^{\prime} 56^{\prime \prime}$ & 576 \\
\hline 'GBK-4’' & Drenas & $20^{\circ} 45^{\prime} 53^{\prime \prime}$ & $42^{\circ} 41^{\prime} 35^{\prime \prime}$ & 694 \\
\hline 'GBK-5’' & Prishtine & $21^{\circ} 04^{\prime} 00^{\prime \prime}$ & $42^{\circ} 35^{\prime} 05^{\prime \prime}$ & 810 \\
\hline GBK-6 & Kamenice & $21^{\circ} 31^{\prime} 32^{\prime \prime}$ & $42^{\circ} 34^{\prime} 16^{\prime \prime}$ & 766 \\
\hline 'GBK-7’’ & Kamenice & $21^{\circ} 25^{\prime} 32^{\prime \prime}$ & $42^{\circ} 33^{\prime} 56^{\prime \prime}$ & 812 \\
\hline 'GBK-8’ & Lipjan & $21^{\circ} 07^{\prime} 20^{\prime \prime}$ & $42^{\circ} 31^{\prime} 45^{\prime \prime}$ & 551 \\
\hline 'GBK-9’' & Podujeve & $21^{\circ} 12^{\prime} 12^{\prime \prime}$ & $42^{\circ} 33^{\prime} 39^{\prime \prime}$ & 598 \\
\hline 'GBK-10’ & Drenas & $20^{\circ} 54^{\prime} 06^{\prime \prime}$ & $42^{\circ} 3450^{\prime \prime}$ & 585 \\
\hline 'GBK-11' & Vushtrri & $21^{\circ} 59^{\prime} 26^{\prime \prime}$ & $42^{\circ} 50^{\prime} 46^{\prime \prime}$ & 557 \\
\hline 'GBK-12' & Ferizaj & $21^{\circ} 09^{\prime} 39^{\prime \prime}$ & $42^{\circ} 22^{\prime} 15^{\prime \prime}$ & 580 \\
\hline 'GBK-13' & Suhareke & $20^{\circ} 49^{\prime} 02^{\prime \prime}$ & $42^{\circ} 21^{\prime} 45^{\prime \prime}$ & 388 \\
\hline 'GBK-14' & Vushtrri & $20^{\circ} 58^{\prime} 30^{\prime \prime}$ & $42^{\circ} 33^{\prime} 38^{\prime \prime}$ & 518 \\
\hline 'GBK-15' & Drenas & $20^{\circ} 42^{\prime} 32^{\prime \prime}$ & $42^{\circ} 39^{\prime} 21^{\prime \prime}$ & 586 \\
\hline 'GBK-16’ & Drenas & $20^{\circ} 42^{\prime} 46^{\prime \prime}$ & $42^{\circ} 39^{\prime} 30^{\prime \prime}$ & 565 \\
\hline 'GBK-17’ & Skenderaj & $20^{\circ} 48^{\prime} 23^{\prime \prime}$ & $42^{\circ} 45^{\prime} 00^{\prime \prime}$ & 623 \\
\hline 'GBK-18' & Skenderaj & $20^{\circ} 47^{\prime} 39^{\prime \prime}$ & $42^{\circ} 4439^{\prime \prime}$ & 597 \\
\hline 'GBK-19’ & Skenderaj & $20^{\circ} 48^{\prime} 04^{\prime \prime}$ & $42^{\circ} 44^{\prime} 39^{\prime \prime}$ & 603 \\
\hline 'GBK-20’ & Shtime & $20^{\circ} 07^{\prime} 06^{\prime \prime}$ & $42^{\circ} 44^{\prime} 40^{\prime \prime}$ & 610 \\
\hline
\end{tabular}

Each plot consisted of a row $5 \mathrm{~m}$ long with an inter and intra row plant spacing of $0.75 \times 0.25 \mathrm{~m}$, resulting in a population density of 53,000 plants ha $\mathrm{a}^{-1}$. Area of individual plots in each replication was $15 \mathrm{~m}^{2}$.

\section{Laboratory studies}

At harvest time, five random ears were selected in each plot, giving a total of 15 ears per individual population. Grains were carefully removed by hand. From each population, an equal number of grains was taken from each plot, mixed together in orders to form a balanced sample and then subjected to proximate analyses in the laboratory. The grains obtained were grounded to form a fine powder. The chemical analyses included protein content (PC), starch content (SC) and oil content (OC). Analyses were based on standard methods: PC was determined by the Kjeldahl, while OC was determined by extraction using Soxhlet method (using petroleum ether at boiling point $40-60^{\circ} \mathrm{C}$ ). Ash contents of each sample were determined by the dried of sample at $550^{\circ} \mathrm{C}$.

\section{Statistical analyses}

All statistical analyses were performed with the SPSS software (version 15.0, SPSS Inc., 2006). Mean values and coefficients of variation were used in the statistical analyses. Effects of the traits were evaluated by ANOVA. In order to asses the differentiation of local maize populations (LMP's) based on all variables that were measured using Canonical Discriminant Analyses (CDA). CDA is a technique for classifying a set of observation into predefined classes. Relationship among different variables of the quality analyses were tested by means of Pearson's correlation test.

\section{Results and discussion}

Significant differences among the LMP's for grain yield and grain quality such as content of oil, protein, starch, ash and moisture were determined (Tab. 2).

The analysis of variance (ANOVA) showed that the LMP's differed for most of the traits studied (Tab. 3). The mean values of the grain yield per plant at LMP's were 79.33 g plant $^{-1}$. It is evident from the present results that local maize population ' $G B K-7$ ' had maximum grain yield per plant $\left(105.13 \mathrm{~g} \mathrm{plant}^{-1}\right)$ which is $25.8 \mathrm{~g} \mathrm{plant}^{-1}$ or $32.52 \%$ higher than the mean values, whereas LMP's on code 'GBK-13' had the lowest grain yield (59.62 g plant $^{-1}$ ) which is $19.71 \mathrm{~g} \mathrm{plant}^{-1}$ or $24.84 \%$ lower than the mean values $\left(79.33 \mathrm{~g} \mathrm{plant}^{-1}\right)$. High oil maize is a special type that has been bred to have higher percent oil content (OC) than regular yellow corn. Typically, oil content of yellow maize varies from 3.5 to $4 \%$. Ideally, high oil maize should contain from 7 to $8 \%$ of oil (Heiniger, 1997). Kernel oil content is considered to be a quantitative trait controlled by numerous genes with small effects (Dudley, 1977). The data showed a relatively wide range among the LMP's for 
128

Tab. 2. Mean squares for grain yield and quality parameters of 20 Kosovo local maize populations

\begin{tabular}{cccccccc}
\hline Sources of variation & d.f. & $\begin{array}{c}\text { Yield } \\
\text { per plant }(\mathrm{g})\end{array}$ & $\begin{array}{c}\text { Oil } \\
\text { content }(\%)\end{array}$ & $\begin{array}{c}\text { Protein } \\
\text { content }(\%)\end{array}$ & $\begin{array}{c}\text { Starch } \\
\text { content }(\%)\end{array}$ & $\begin{array}{c}\text { Ash } \\
\text { content }(\%)\end{array}$ & $\begin{array}{c}\text { Moisture } \\
\text { content }(\%)\end{array}$ \\
\hline LMP's & 19 & $2.895^{* *}$ & $2.863^{* *}$ & $18.593^{* *}$ & $4.584^{* *}$ & $2.863^{* *}$ & $247.49^{* *}$ \\
CV\% & & 18.26 & 13.37 & 4.40 & 1.49 & 3.10 & 3.62 \\
Error & 38 & 217.46 & 0.0019 & 0.0437 & 0.728 & 0.0019 & 0.003 \\
\hline
\end{tabular}

** Significant at $p=0.01$

Tab. 3. Means values of grain yield and quality characters in Kosovo local maize populations

\begin{tabular}{|c|c|c|c|c|c|c|}
\hline $\begin{array}{l}\text { Local maize } \\
\text { populations }\end{array}$ & $\begin{array}{c}\text { Ash content } \\
(\%)\end{array}$ & $\begin{array}{c}\text { Oil content } \\
(\%)\end{array}$ & $\begin{array}{c}\text { Moisture content } \\
(\%)\end{array}$ & $\begin{array}{c}\text { Protein content } \\
(\%)\end{array}$ & $\begin{array}{c}\text { Starch content } \\
(\%)\end{array}$ & $\begin{array}{c}\text { Yield } \\
\left(\text { plant }^{-1} \mathrm{~g}\right)\end{array}$ \\
\hline 'GBK-1' & $1.44 \pm 0.020$ & $4.37 \pm 0.032$ & $14.48 \pm 0.030$ & $13.02 \pm 0.215$ & $68.58 \pm 0.535$ & $69.69 \pm 1.060$ \\
\hline 'GBK-2' & $1.38 \pm 0.028$ & $4.53 \pm 0.316$ & $14.14 \pm 0.040$ & $11.69 \pm 0.049$ & $69.87 \pm 0.640$ & $88.97 \pm 9.763$ \\
\hline 'GBK-3’' & $1.33 \pm 0.080$ & $3.83 \pm 0.520$ & $14.56 \pm 0.005$ & $12.50 \pm 0.205$ & $70.70 \pm 0.362$ & $102.55 \pm 7.230$ \\
\hline 'GBK-4' & $1.38 \pm 0.025$ & $4.01 \pm 0.198$ & $14.84 \pm 0.085$ & $11.75 \pm 0.280$ & $70.96 \pm 0.753$ & $93.30 \pm 5.863$ \\
\hline 'GBK-5' & $1.39 \pm 0.055$ & $5.57 \pm 0.456$ & $14.16 \pm 0.045$ & $11.59 \pm 0.176$ & $69.97 \pm 0.761$ & $86.29 \pm 14.657$ \\
\hline GBK-6 & $1.34 \pm 0.051$ & $4.30 \pm 0.445$ & $14.85 \pm 0.020$ & $11.72 \pm 0.200$ & $70.19 \pm 0.223$ & $82.08 \pm 21.328$ \\
\hline ‘GBK-7’ & $1.34 \pm 0.035$ & $4.78 \pm 0.413$ & $14.14 \pm 0.040$ & $11.32 \pm 0.202$ & $70.43 \pm 0.355$ & $105.13 \pm 11.017$ \\
\hline 'GBK-8' & $1.28 \pm 0.045$ & $4.31 \pm 0.518$ & $14.50 \pm 0.078$ & $11.05 \pm 0.435$ & $72.15 \pm 1.162$ & $82.43 \pm 4.787$ \\
\hline 'GBK-9’' & $1.35 \pm 0.015$ & $4.49 \pm 0.181$ & $14.67 \pm 0.075$ & $11.02 \pm 0.258$ & $70.02 \pm 0.920$ & $99.86 \pm 8.741$ \\
\hline 'GBK-10’ & $1.35 \pm 0.032$ & $4.27 \pm 0.208$ & $14.45 \pm 0.005$ & $11.64 \pm 0.081$ & $70.23 \pm 0.309$ & $78.34 \pm 17.001$ \\
\hline 'GBK-11' & $1.34 \pm 0.043$ & $4.37 \pm 0.457$ & $14.56 \pm 0.046$ & $11.59 \pm 0.134$ & $70.92 \pm 0.453$ & $69.83 \pm 17.969$ \\
\hline 'GBK-12' & $1.31 \pm 0.052$ & $4.40 \pm 0.705$ & $14.07 \pm 0.015$ & $11.15 \pm 0.223$ & $70.68 \pm 0.850$ & $75.77 \pm 17.339$ \\
\hline 'GBK-13' & $1.36 \pm 0.030$ & $2.56 \pm 0.181$ & $16.42 \pm 0.111$ & $11.99 \pm 0.161$ & $70.36 \pm 0.420$ & $59.62 \pm 16.243$ \\
\hline 'GBK-14' & $1.36 \pm 0.023$ & $4.66 \pm 0.408$ & $14.61 \pm 0.077$ & $11.92 \pm 0.217$ & $70.34 \pm 1.125$ & $78.43 \pm 3.458$ \\
\hline 'GBK-15' & $1.45 \pm 0.070$ & $4.44 \pm 0.866$ & $14.19 \pm 0.043$ & $12.49 \pm 0.308$ & $68.63 \pm 1.341$ & $85.47 \pm 16.479$ \\
\hline 'GBK-16’ & $1.43 \pm 0.032$ & $4.89 \pm 0.394$ & $14.24 \pm 0.062$ & $12.52 \pm 0.070$ & $67.39 \pm 0.747$ & $67.36 \pm 29.061$ \\
\hline 'GBK-17’ & $1.38 \pm 0.026$ & $4.67 \pm 0.050$ & $14.01 \pm 0.075$ & $11.86 \pm 0.160$ & $69.41 \pm 0.660$ & $72.67 \pm 15.445$ \\
\hline 'GBK-18' & $1.36 \pm 0.060$ & $5.25 \pm 0.728$ & $14.10 \pm 0.010$ & $11.67 \pm 0.081$ & $69.33 \pm 1.236$ & $67.21 \pm 14.839$ \\
\hline 'GBK-19’ & $1.37 \pm 0.023$ & $4.85 \pm 0.496$ & $14.63 \pm 0.026$ & $12.11 \pm 0.209$ & $69.24 \pm 1.400$ & $74.39 \pm 18.798$ \\
\hline 'GBK-20’ & $1.41 \pm 0.047$ & $4.34 \pm 0.699$ & $14.18 \pm 0.095$ & $11.60 \pm 0.081$ & $70.40 \pm 1.013$ & $47.33 \pm 10.565$ \\
\hline Mean & 1.36 & 4.44 & 14.48 & 11.81 & 69.90 & 79.33 \\
\hline $\mathrm{CV} \%$ & 3.10 & 13.37 & 3.62 & 4.40 & 1.49 & 18.26 \\
\hline
\end{tabular}

Tab. 4. Summary statistics for canonical discriminant standardized functions

\begin{tabular}{ccccccc}
\hline & \multicolumn{7}{c}{ Discriminant functions } & & \\
\hline & 1 & 2 & 3 & 4 & 5 & 6 \\
\hline Eigenvalue & 179.22 & 12.26 & 5.24 & 1.72 & 1.14 & 0.29 \\
Percentage of variation & 89.70 & 6.10 & 2.60 & 0.90 & 0.60 & 0.10 \\
\hline Cumulative percentage & 89.70 & 95.80 & 98.40 & 99.30 & 99.90 & 100.00 \\
Canonical correlation & 0.99 & 0.96 & 0.91 & 0.79 & 0.73 & 0.47 \\
\hline Wilks' Lambda & 0.00 & 0.002 & 0.021 & 0.132 & 0.360 & 0.771 \\
\hline Chi-square & 535.17 & 296.24 & 177.31 & 93.04 & 46.98 & 11.97 \\
\hline df & 114 & 90 & 68 & 48 & 30 & 14 \\
\hline Significance & $<0.001$ & $<0.001$ & $<0.001$ & $<0.001$ & 0.025 & 0.608 \\
\hline Elements of Structure Matrix & & & & & \\
\hline Ash Content (\%) & 0.003 & 0.291 & -0.065 & -0.209 & -0.029 & $0.931^{\circ}$ \\
\hline Oil Content (\%) & -0.095 & -0.005 & 0.133 & -0.431 & -0.145 & 0.876 \\
\hline Moisture (\%) & 0.789 & -0.549 & 0.261 & -0.019 & -0.070 & 0.042 \\
\hline Protein Content (\%) & 0.053 & 0.752 & 0.503 & -0.135 & -0.188 & -0.354 \\
\hline Starch Content (\%) & 0.015 & -0.296 & -0.004 & 0.685 & 0.471 & -0.470 \\
\hline Grain yield (\%) & -0.019 & -0.082 & 0.092 & 0.506 & -0.800 & 0.296 \\
\hline
\end{tabular}

${ }^{*}$ Largest absolute correlation between each variable and any discriminant function 
Tab. 5. Pearson's correlations among yield and grain quality traits of investigated populations

\begin{tabular}{cccccc}
\hline Trait & Yield & $\begin{array}{c}\text { Oil } \\
\text { content } \\
(\%)\end{array}$ & $\begin{array}{c}\text { Protein } \\
\text { content } \\
(\%)\end{array}$ & $\begin{array}{c}\text { Starch } \\
\text { content } \\
(\%)\end{array}$ & $\begin{array}{c}\text { Ash } \\
\text { content } \\
(\%)\end{array}$ \\
\hline $\begin{array}{c}\text { Oil } \\
\text { content }(\%)\end{array}$ & 0.12 & & & & \\
$\begin{array}{c}\text { Protein } \\
\text { content }(\%)\end{array}$ & -0.19 & -0.12 & & & \\
$\begin{array}{c}\text { Starch } \\
\text { content }(\%)\end{array}$ & $0.33^{*}$ & -0.15 & $-0.68^{*}$ & & \\
$\begin{array}{c}\text { Ash } \\
\text { content }(\%)\end{array}$ & $-0.30^{*}$ & 0.17 & $0.69^{*}$ & $-0.58^{*}$ & \\
$\begin{array}{c}\text { Moisture } \\
\text { content (\%) }\end{array}$ & -0.15 & $-0.80^{* *}$ & 0.09 & 0.14 & -0.15 \\
\hline *means significant at $p=0.05$ & & & & \\
\hline
\end{tabular}

this trait. The mean value of the OC was $4.44 \%$. The genotype 'GBK-5' exhibited maximum OC on value $5.57 \%$, while 'GBK-13' had the lowest value of OC (2.56\%). Different ranges of variation (5.26 and 7.17\%) were observed by Berardo et al. (2009). Has et al. (2009) reported different values which varied from 0.04 to $12.3 \%$. Significant values of OC were also reported by Saleem et al. (2008).

The variation in protein content $(\mathrm{PC})$ was found to be higher than variation in OC. The ANOVA indicated that the differences among the LPM's for PC were highly significant (Tab. 3). The mean value of PC observed in the present study was $11.81 \%$. Some of LMP's were identified with high grain PC ranging from 11.02 to $13.02 \%$. This can be regarded as a relatively high level of PC. The LMP's also showed a high genetic variation (16.93\%). The variation of the protein content has been well demonstrated by numerous studies. Has et al. (2009) at some LMP's reported variation from 11.2 to $15.6 \%$; while Prasanna et al. (2001) presented different results which varied from 8.9 to $10.2 \%$. From the data shown in Tab. 3 it is evident that the starch content (SC) of maize kernels depends to a very large extent on genotype of population. The starch content (SC) ranging between 67.39 and $72.15 \%$, while the grand mean values of SC was $69.90 \%$. There were significant differences at $p=0.01$. Similar results ( 58.1 to $72 \%)$ for $S C$ in different LMP were reported by Has et al. (2009). Also, ash content $(\mathrm{AC})$ was with variation which ranged from 1.28 to $1.45 \%$.

Tab. 4 described the canonical discriminant functions, the eigenvalue, percentages of variation of each function and the cumulative variance of the six discriminant functions. This table also shows the standardized elements of structure matrix. The first two canonical discriminant functions were significant $(p<0.01)$. It is important to point out the great relevance of the first two discriminant functions justifying $95.80 \%$ of the variability. The first discriminant function showed a significant positive correlation with the moisture (0.789) following by protein and starch content $(0.053$ and 0.015$)$. But, the negative correlation (-0.019) was determined between first descriminant function and grain yiled (Tab. 5).

Maize breeders expect that kernel protein and oil content should be negatively correlated with yield per plant. In the present study, grain yield per plant was positively and significantly correlated with starch content $\left(\mathrm{r}=0.33^{*}\right)$, nonsignificant and positively correlated with oil content $(r=0.12)$ but it was nonsignificant and negatively correlated with protein content $(\mathrm{r}=-0.19)$ (Tab. 5). The possible cause of such relations between nutritional qualities with

\section{Canonical Discriminant Functions}

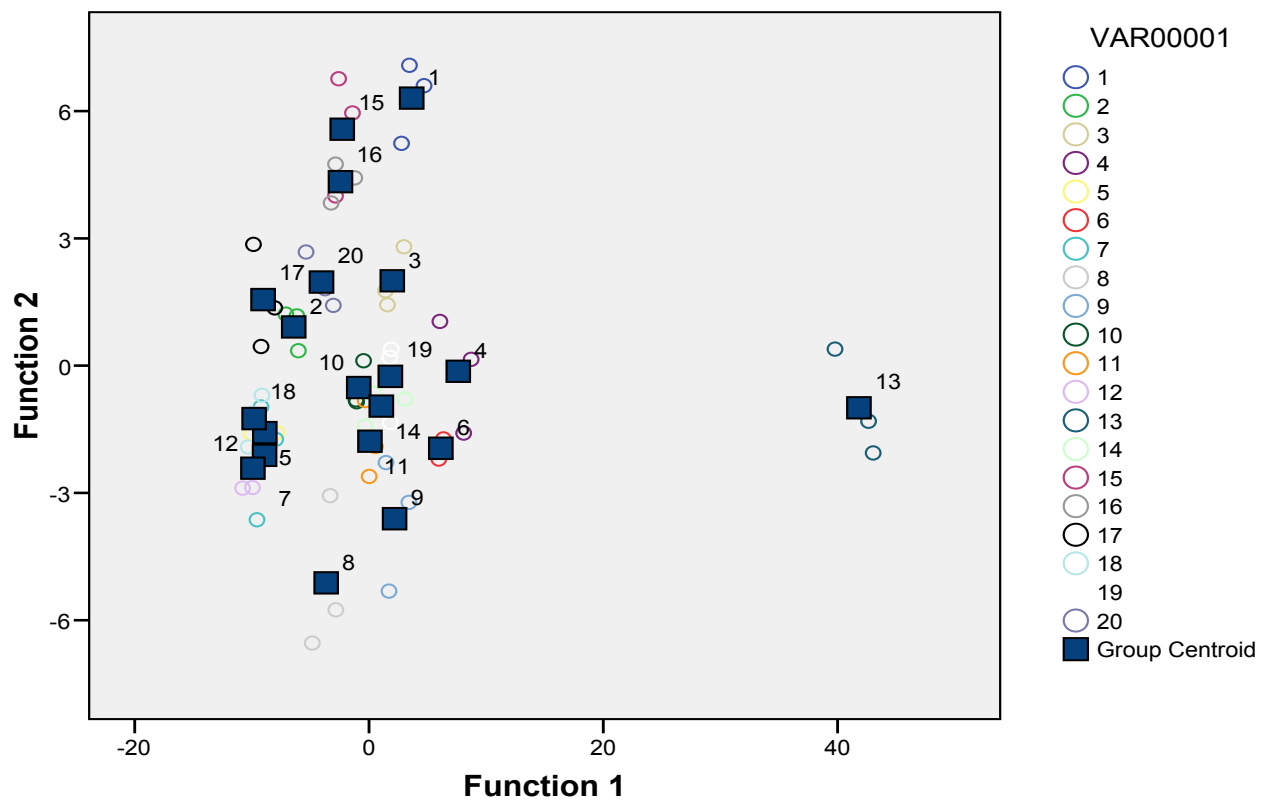

Fig. 1. Canonical disriminant analyses of local maize populations by grain yield and quality characteristics 
130

yield was probably due to reduction of starch content in the grains. The present results are in partially agreement with the results of Has et al. (2009) and Saleem et al. (2008).

The canonical discriminant analysis of the traits is presented in Fig. 1. The first canonical functions described $89.7 \%$ and a second canonical function is $6.1 \%$ of the existing variance. Ash content had the strongest influence in the Function 1, while the Functions 2 was mostly influenced by the Oil content (OC) followed by protein content (PC) and starch content (SC).

\section{Conclusions}

The study showed that there was a significant genetic variability in many traits among studied local maize populations. High variability was determined for PC, OC and SC. Positive and significant correlations were found between yield and starch contents. Negative correlation was found between yield and protein content. The first canonical functions described $89.7 \%$ and a second canonical function is $6.1 \%$ of the existing variance. The investigated maize populations can be considered as a source of new genetic variability, and can be successfully used for the development of maize inbred in the further breeding program. The evaluation of germplasm resources has been considered of prime importance, especially on those species that have a further economic interest.

\section{Acknowledgement}

The first author gratefully acknowledges the National Gene Bank of Kosovo for providing maize plant material which was included in this study.

\section{References}

Berardo N, Mazzineli G, Valoti P, Lagana R, Redaelli R (2009). Characterization of maize germplasm for the chemical composition of the grain. J Agr Food Chem 57:2378-2384.

Bjarnason M, Vasal K (1992). Breeding quality protein maize (QPM). Plant Breed Rev 9:181-216.

Dudley J (1977). Seventy-six generations of selection for oil and protein percentage in maize. Book of Proc of the International Conference on Quantitative Genetics. ISU, 459-473.

Egesel OC, Kahriman F, Gul M (2011). Discrimination of maize inbreeds for kernel quality traits and fatty acid composition by a multivariate technique. Acta Sci Agron 33(4):613-620.

FAO (1988). Food and Agriculture Organization. www.fao. org/docrop.
Glover D, Mertz T (1987). Nutritional quality of cereal grains. Agron Monograph 28:183-336.

Gou B, Chen Z, Brown R, Lax A, Cleveland E, Russin D (1997). Germination induces accumulation of specific proteins and antifungal activities in corn kernels. Phytopathol 87:11741178.

Has V, Has I, Pamfil D, Copandean A, Campean S (2009). Evaluation of turda maize gerplasm for phenotypic variability in grain chemical composition. Maydica 54:313-320.

Haumann B (1996). Corn research looks at changing oil content. Inform 7:576-583.

Heiniger R, Dunphy J (1997). High oil corn production Q\&A. NC State University, 22-28 p.

Jugenheimer RW (1961). Breeding for oil and protein content in maize. Euphytica 10:152-156.

Lambert RJ (2001). High-oil corn hybrids, 123-145 p. In: Speciality corns. Hallauer AR (Ed.). CRC Press, Boca Raton.

MAFRD (2010). Ministry of Agriculture, Forestry, Rural Development of Kosovo, Statistics Division. Database for Sum of temperatures and rainfall.

Micu V, Partas V, Rotari I (1995). The revealing and selection of high protein sources of maize. Maize Gen Coop Newslett 69:115-116.

MINITAB-14 (2008). www.minitab.com/contacts.

Mittelman A, Filho J, Lima G, Klain C, Tanaka R (2003). Potential of the ESA23B maize population for protein and oil content improvement. Sci Agricola 60:319-327.

Okoruwa VO, Jabbar MA, Akinwumi JA (1996). Crop-livestock competition in the West African Derived Savannah: Application of a multiobjective programming model. Agric Systems 52:439-452.

Oliveria J, Chaves L, Duarte J, Ribeiro K, Brasil E (2006). Heterosis for oil content in maize populations and hybrids of high quality protein. Crop Breed Apl Biotechn 6:113120.

Prasanna M, Vasal K, Kassahun B, Singh N (2001). Quality protein maize. Current Sci 81:1308-1319.

Saleem M, Ahsan M, Salam M, Majeed A (2008). Comparative evaluation and correlation estimates for grain yield and quality attributes in maize. Pak J Bot 40(6):2361-2367.

SPSS-15 (2006). Statistical package programme.

Weber E (1987). Lipids of the kernel, 311-349 p. In: Corn Chemistry and Technology. Watson SA, Ramstad PE (Eds.). Am Assoc Cereal Chem Inc St Paul, MN. 